A linguagem sobrevém da necessidade de conserva o objeto além da satisfação da necessidade, sendo portanto, resultado da atividade pulsional. Nesse processo, o objeto da pulsão invocante e o da pulsão alimentar se substituem um ao outro. A articulação da psicolingüística com a psicanálise ajuda a compreender melhor como isso acontece na medida em que uma observa os comportamentos e a outra supõe desejos subjacentes a esses comporta mentos, revelando que todos os comportamentos do bebê são o reflexo de sua atividade pulsional e de sua entrada progressiva na linguagem. A palavra faz com que os objetos perdurem e que possam ser reconhecidos.

Pulsão; seio; voz; desejo; psicolingüística; palavra

ENTERING IN THE

LANGUAGE

Language arises from the need to maintain the object beyond necessity, thus being consequence of drive activity. In this process, the object of the invoking drive and the nourishing drive replaces one another. The articulation of psycholinguistics with psychoanalysis helps to understand how this takes place, since the first observes behaviors and the latter supposes underlying desires to these behaviors, unveiling that all the baby's behavior is reflection of its drive activity and of its gradual ingress into language. The word allows objects to last and to be recognized.

Drive; breast; voice; desire; psycholinguistics; word

\section{ENTRANDO NA LINGUAGEM}

\author{
Telma Corrêa da Nóbrega Queiroz
}

(2)

uando Lacan nos diz no Seminário II (1954-5) que todos os objetos não são infinitamente duráveis, que eles podem desaparecer, e que é a nomeação que faz com que perdurem e possam ser reconhecidos, ele nos mostra assim que a linguagem sobrevém da necessidade de conservar o objeto além da satisfação da necessidade, pois de outra maneira ele desapareceria para sempre. Procurar o objeto da falta e tentar restaurar a perda original é a própria atividade da pulsão, e é essa atividade que está na origem da linguagem. A construção da pulsão já é em si uma construção de linguagem - eu-sujeito/ verbo/objeto-mundo externo -, os tempos verbais que exprimem sua atividade conjugam-se sob a forma direta ou reflexiva, a pulsão nos introduz não somente às palavras, mas também à gramática. A palavra, portanto, não é mais que uma atividade da pulsão oral, assim como a sucção, a mordida e a deglutição, pois a pulsão oral tem a particularidade de reunir no mesmo órgão, na mesma fonte que é a boca, duas funções diferentes, a função alimentar e a palavra.

- Psiquiatra, psicanalista, doutora em Psicologia pela Universidade de Paris XIII, professora de Psicologia Médica da UFPB, membro do Fórum Psicanalítico de João Pessoa e do Grupo Psicanálise e Pediatria de Recife e João Pessoa. 
A pulsão constrói-se em cima da função orgânica. Mas desde o início as necessidades e as funções são regidas pelo significante. A demanda do Outro direciona progressivamente a libido da criança para as zonas erógenas, a boca sendo a primeira delas, a que predomina durante o primeiro ano de vida. O corpo e suas funções são progressivamente aspirados e subordinados à demanda do Outro, o Outro que é também o lugar do significante.

Como se manifesta a pulsão? A pulsão manifesta-se por uma tensão que surge da descontinuidade inaugurada pelo nascimento. Essa tensão aparece, sobretudo, no funcionamento dos orifícios, lugares erógenos que fazem com que o essencial do investimento dirija-se para a relação oral, ou seja, para a relação ao seio. Freud (1905) chamou esse primeiro momento de fase oral.

Nesse momento, a permanência da presença humana e a constância do rosto são de uma importância fundamental para o surgimento da representação e do pensamento, sem o que a criança jamais poderia falar. O ritmo da amamentação introduz a criança na ausência e na falta, ritmo que é também o jogo de presença/ ausência, que por sua vez faz sobrevir a representação. A criança começa a falar procurando reproduzir esse ritmo. Essa capacidade de reproduzir estruturas rítmicas seria, aliás, condição prévia para a entrada na linguagem, pois o bebê se introduz primeiro na música, no ritmo, na freqüência e na melodia da palavra antes de chegar ao sentido.

Freud (1895) descreveu o processo de entrada na linguagem e no simbólico, no Projeto de psicologia para neurólogos, partindo da construção de um aparelho muito complicado, o aparelho psíquico, que é montado em cima do conceito de pulsão, sendo a primeira inscrição fundadora determinada pela primeira experiência de satisfação no seio.

Por que a atividade pulsional procura conservar o objeto além da satisfação da necessidade? Freud nos diz, em $O$ mal-estar na civilização (1929), que é a felicidade e a harmonia que os homens procuram, porque alguma coisa lhes falta que os impede de serem felizes. A felicidade seria em princípio reencontrar o objeto que preencheria a falta, o que constitui ao mesmo tempo um paradoxo, pois não mais sentir a falta seria a morte, nada mais teríamos a procurar, nada mais se produziria. A felicidade e a harmonia são apenas um mito, jamais encontramos o objeto que preenche a falta. Somos assim condenados a procurar objetos substitutivos que nunca nos satisfazem inteiramente, e, entre esses objetos, nos confrontamos com os fonemas e as palavras que nos permitem investir o mundo. As palavras, a fala, são uma maneira encontrada pelos homens de fazerem perdurar o objeto perdido além de sua ausência, 
as palavras substituem o seio quando este se perde. Melanie Klein (1952) nos diz que o fato de falar e também o de andar e o de ficar em pé são maneiras de os homens ultrapassarem a posição depressiva e compensarem a perda do objeto, tão difícil de suportar.

Mas as palavras só preenchem essa função quando reenviam a uma experiência sensorial que foi acompanhada por palavras. É o que nos diz Françoise Dolto em seu livro $A$ imagem inconsciente do corpo (1984). As palavras com as quais pensamos e falamos, as palavras que estão na origem de nossa linguagem são as palavras que acompanharam as imagens do corpo no contato com outrem, palavras que simbolizam, portanto, uma experiência sensorial, o que nos faz compreender como as palavras fazem durar a presença do Outro em sua ausência. Para Gérard Pommier (1998), é a aspiração pela ausência de ser que impele o sujeito a querer falar, a jubilar e a gozar de sua palavra. O sujeito procura encontrar seu ser graças ao amor, graças à presença do Outro, e a palavra serve para isso, para procurar o Outro, para fazer voltar o Outro ausente. É a ausência de ser que faz com que os homens queiram conservar os objetos além da necessidade, e é isso que constitui a atividade pulsional.

Enfim, podemos dizer que os homens procuram suprir a ausência de ser pelo amor do Outro, que o amor é idealmente o que poderia trazer-lhes a felicidade, e que a linguagem seria apenas uma maneira de pedir o amor do Outro e de procurar a felicidade, uma maneira também de fazer durar a presença do outro e de substituir o primeiro objeto da experiência de satisfação, o seio, o objeto da nostalgia, que traria de novo o sentimento oceânico. A linguagem já é em si mesma demanda de amor e presentificação do Outro, são as palavras que nos permitem suportar a perda, é com palavras que a criança preenche a boca esvaziada do seio.

Embora a pulsão coabite com a função desde o início, vamos, no entanto, para guardar a clareza de nossa exposição, passar da função à pulsão, e da pulsão à linguagem. Como a amamentação, a linguagem é também uma atividade que só surge na intersubjetividade, e nesse processo um e outro dos parceiros implicados se confundem, se põem um no lugar do outro, se transitivam, se reúnem e se separam.

Mas uma criança só pode falar se ela está mergulhada num banho de linguagem desde a vida intra-uterina. A criança está desde as origens, mergulhada no grande Outro, ela é aspirada pelo Outro, lugar da linguagem e lugar do simbólico, ela é aspirada por esse meio Outro que está presente, sobretudo, nos momentos de cuidados, nos momentos de amamentação. Outro que num primeiro tempo é a mãe, o leite, o seio, de quem a criança é total- 
mente dependente para sua sobrevivência. Essa dependência do $\mathrm{Ou}-$ tro devido à prematuração do nascimento própria do ser humano, Freud chamou Hilflosigkeit (1925-6), o desamparo, o que em termos lacanianos podemos exprimir como falta a ser.

O meio sonoro intra-uterino é constituído por ruídos biológicos fetais e maternos, mas também por numerosos ruídos externos que chegam até o feto, entre os quais, as vozes. Desde antes do nascimento e mesmo depois, a voz é de uma importância fundamental na construção do sujeito. Ela é o objeto da pulsão invocante, é incorporada da mesma maneira que o alimento, a voz também desencadeia movimentos de sucção. A pulsão invocante, diz AlainDidier Weill (1998), é o que impele o corpo a se arrancar de sua materialidade pesante e que nos põe em movimento para um ponto terceiro, para o grande Outro, em direção à entrada na linguagem e à submissão às leis da fala.

A voz é suporte da diferença, pois, nos diz Denis Vasse (1977), nela se encontra a marca particular do sujeito. Mas a voz é também o suporte da palavra que parte de um sujeito se dirigindo para o Outro e da demanda que ela transmite. É a voz da mãe ou do pai, que profere o nome próprio, e é também pela $\mathrm{VOz}$ que o sujeito é referido ao desejo do Outro. Segundo Françoise Dolto (1984), o recém-nascido só se pode desenvolver num corpo se ele está em relação com uma voz de homem e de mulher, quer dizer, é preciso que haja uma outra voz associada com a 
voz de sua mãe. O pai é aquele que barra a mãe, que encarna a lei da proibição do incesto e que exerce um poder dinamizante sobre ela.

A voz mostra-nos ainda que o sujeito ultrapassa seus limites corporais, ela funciona de certa maneira como os tentáculos de um polvo que avançam no espaço e tocam no corpo do outro em todos os seus pontos, ela indica a presença à distância. Podemos compará-la com a lamínula, o órgão da libido, ela é mesmo constituinte desse órgão assim como o seio, o que mostra que o verdadeiro limite do ser do organismo vai bem mais longe do que o corpo. Da mesma maneira que o seio, a voz é ectopia de um indivíduo sobre outro, portanto, também se presta ao corte. Ela tem, aliás, o mesmo poder erotizante.

A tensão pulsional, a fome, faz reproduzir no imaginário do bebê, as imagens dos encontros precedentes com a lembrança dos sons desses encontros. A voz da mãe é, portanto, reproduzida na simultaneidade da imagem. Uma das percepções, entre a simultaneidade, uma cor, um som que se repete, a imitação de um movimento, a alucinação de um odor, uma palavra que acompanha a imagem do corpo restabelece imaginariamente o cenário do encontro com o objeto primordial que está ausente. Uma palavra pode assim reativar o traço mnésico inconsciente inscrito no aparelho psíquico e reproduzir imaginariamente a experiência de satisfação não somente do seio, mas também da voz, do olhar e do cheiro. Pela introdução do imaginário, a lembrança da experiência passada toma corpo. Esse imaginário é, de saída, marcado pelo simbólico, pois a reprodução compreende as imagens sonoras das palavras. É a própria voz, ou as imagens sonoras reproduzidas que vão permitir à criança esperar o momento da satisfação e renunciar ao objeto, o que, por sua vez, o levará a fazer lalações, a pensar e a falar. Por seus sons, ela acredita ouvir novamente sua mãe, ela a vê em imagens, reproduzindo ativamente assim a experiência de satisfação.

$\mathrm{Na}$ voz que fala podemos distinguir o som e o sentido. $\mathrm{O}$ som é a melodia com o ritmo, é a música da linguagem. Mas a emissão da palavra e dos sons acompanha-se, além disso, de gestos não somente na pessoa que fala, mas provoca também movimentos no corpo daquele que escuta, da mesma maneira que a própria música. Tanto para o feto, quanto para o bebê, a voz constitui um estímulo pulsional, que tem um efeito diretamente no corpo, produzindo variações dos ritmos fisiológicos, modificações da tensão muscular, atividades motoras, notadamente atividade de sucção, elevação do tônus e aumento da vigilância, nisso em que se vê como a voz toca diretamente o corpo. Ninguém ignora, aliás, os efeitos da palavra e dos sons no corpo dos adultos e das crianças. Foi procurando ouvir novamente a vOz do outro em sua ausência que o ser humano inventou os instrumentos musicais, assim como os meios de comunicação à distância. Sabe-se que a música produz modificações dinamogênicas no corpo, modificações que são devidas à cadência, ao ritmo e à melodia. A música é, sobretudo, 
o resultado do esforço para reproduzir a voz humana, a voz do outro, a voz da mãe, que era escutada na simultaneidade do seio. Seus efeitos no corpo do próprio adulto são conhecidos há muito tempo e constituem o fundamento das terapias musicais. Ela age sobre o sistema nervoso e muscular, com elevação ou diminuição do tônus, produção de energia motora ou abaixamento de tensão, conforme o tipo de música.

De um ponto de vista anátomo-fisiológico, as duas atividades do ouvido explicam a intimidade do som com os gestos, os movimentos e o ritmo. A primeira é a atividade vestibular, que assegura a estática e a cinética, assim como a posição relativa de cada um dos membros; a outra, é a atividade coclear, que diferencia os sons em suas alturas tonais, suas qualidades espectrais, em suma, suas composições freqüenciais. É a cóclea que percebe os sons, enquanto o vestíbulo retifica a posição, determinando a verticalidade do conjunto do corpo. Considera-se que a música prepara de certa forma o corpo e o sistema nervoso para a linguagem, e é a linguagem que o esculpe pela construção da imagem inconsciente do corpo. E, se essa música vem da voz que fala nos momentos de cuidados, ela transmite, além disso, o desejo e a demanda do Outro, o que faz com que, mais tarde, a música sozinha possa trazer a nostalgia que é não somente do seio e da voz, mas, sobretudo, do desejo e do encontro com o Outro. A emoção musical seria assim, de certa maneira, reatualização da emoção sexual dos encontros primordiais recalcados, trazendo à memória outras representações que viriam se superpor à da voz da mãe, percebida no passado na simultaneidade do seio e de seus substitutos sucessivos, ao mesmo tempo em que a emoção sentida corporalmente naquele momento. Se "a música, essa infortunada, constrangida a se desenvolver no tempo" (Freud, 1910, p. 21; nossa tradução), como a descreve Leonardo da Vinci (citado por J.-B. Pontalis no prefácio de Un souvenir d'enfance de Léonard de Vinci), nos introduz à sucessividade, a reação corporal é entretanto simultânea ao som. Ela provoca, por exemplo, simultaneamente um gesto, um movimento, a alteração de um ritmo corporal, ou um passo de dança, como nos lembra Alain-Didier Weill (1998). A harmonia, por outro lado, ou seja, a maneira pela qual os sons combinam-se em acordes, nos reenvia à simultaneidade. A melodia e o ritmo, em seu desenrolar no tempo, nos introduzem à sucessividade, embora não ainda ao sentido, pois não é preciso esperar a última palavra para compreender, o efeito é simultâneo. A música é a única linguagem, nos diz Alain-Didier Weill (1998), que permite o encontro imediato, absoluto.

Essa primeira etapa na construção da subjetividade lembranos o cinema mudo, que, com efeito, não era inteiramente mudo, 
era cinema musical, pois o filme era sempre acompanhado por uma música que sugeria o sentido dos movimentos que se desenrolavam na tela, a música era assim puro significante, que podia se prender aos significados de cada um. As músicas que acompanhavam as cenas sugeriam diálogos, perseguições, com aceleração ou lentificação dos movimentos, gravidade ou acuidade dos sons, agressividade ou doçura da interpretação, deixando perceber as intenções, a alegria, a tristeza, o amor, o ódio, o terror, o suspense, as interrogações, as surpresas, dos personagens de um filme. A linguagem musical continua, aliás, a ter um papel muito importante nos filmes falantes.

A música da fala da mãe, da palavra da mãe, com suas inflexões, suas entonações, suas modulações variadas, seus silêncios, suas escansões e seus ritmos, constitui o que se chama a prosódia. A mãe tem uma maneira particular de falar à criança, uma prosódia particular que se convencionou chamar o "manhês", na ausência do que a criança corre o risco de ficar aquém de todo discurso. É como se a ausência dessa prosódia implicasse que não haveria endereçamento para a criança, que ela não seria reconhecida como sujeito de desejo. Além disso, em sua maneira de falar, como a música do cinema mudo, a mãe pode transmitir suas emoções, seu ardor, seu tédio, sua alegria, sua angústia, manifestações que, para um outro adulto, podem ser mascaradas pelo jogo das significações, pelo fato de que a voz é tomada na linguagem, mas que são, assim mesmo, absorvidas pelo bebê, pelo lactente. Pela sua maneira 
de falar, nos diz Alain-Didier Weill, a mãe transmite seus dilemas e a solução que dá a esses dilemas. Se, por acaso, a mãe está deprimi$\mathrm{da}$, a musicalidade de sua palavra sofre, sua cadeia sonora torna-se monótona, sem entonação, sem melodia, o que pode ter efeitos desestruturantes no feto e no bebê. Segundo Marie-Christine Laznik (1998), a prosódia materna lembra o chiste, ou seja, tem uma estrutura interrogativa que é ao mesmo tempo manifestação de surpresa, reenviando a uma terceira pessoa. Através dessa estrutura prosódica, a mãe transmitiria sua falta à criança. A ausência dessa estrutura prosódica na palavra dela estaria na origem do autismo.

O som da voz da mãe, portanto, faz o bebê entrar em ressonância com ela, suscita a troca, o encontro, o diálogo e a comunicação. A voz da mãe transmite uma palavra que introduz a criança pouco a pouco no mundo simbólico, no jogo de substituições e das nomeações: dedo, chupeta, brinquedo, mamadeira, alimento, palavra. Dolto (1984) nos diz que os sons emitidos pela mãe, chegando aos ouvidos da criança, estabelecem zonas erógenas, ao mesmo tempo em que as palavras tomam corpo. Corpo que é antes de tudo seu próprio corpo acoplado, num primeiro tempo ao corpo materno. E assim que as funções do corpo são pouco a pouco aspiradas pelo significante. Essa substituição da mãe por outros objetos institui na criança a capacidade de metaforização, metáfora que é antes de tudo a do laço com o corpo de sua mãe. As palavras só tomam sentido ao tomarem corpo, metabolizadas nessa relação entre mãe e filho, o que nos mostra como as duas funções da boca, a de comer e a de falar, se telescopam. Como o objeto da pulsão alimentar, o seio, e o da pulsão invocante, a voz, são intercambiáveis. A voz materna e o seio são incorporados na sucção não-nutritiva, assim como o leite na sucção nutritiva. Wallon (1983) nos diz que as primeiras excitações exteroceptivas capazes de suscitar na criança reações significativas parecem ser excitações auditivas, e ele cita a senhora Ch. Bülher, que, nos anos 30, já tinha constatado que a voz humana era ligada à vontade de mamar.

Do lado da criança, nos diz Denis Vasse (1977), a voz sobrevém quando o umbigo se fecha, com o grito, primeiro som proferido pela voz do bebê, grito que é uma reação de angústia às perturbações da economia libidinal, grito que corta o silêncio, mas que se torna, segundo Freud (1895), o precursor da linguagem. Depois desse primeiro grito, que acompanha a entrada em jogo da respiração, é também pelo grito que o bebê vai procurar acalmar sua tensão, o que a mãe vai interpretar como demanda, como apelo ao Outro, introduzindo dessa maneira a criança na comunicação significante. A linguagem sobrevém, portanto, para o bebê, desse investimento como sentido para a mãe, pelo fato de que ela vem, ela lhe 
traz o seio quando ele grita ou chora. O próprio fato de trazer o seio, em si, já dá sentido aos gritos e ao choro. Em seguida, qualquer som da criança a mãe vai interpretar como apelo, como demanda e vai significá-lo à criança. Se essa interpretação falta, o grito não pode se transformar em palavra, ele pode se manter puro grito, ou ser interpretado simplesmente como manifestação de hostilidade. Outras manifestações no recém-nascido fora o grito, tais como certas expressões mímicas, o sorriso, estirar a língua para o adulto, seriam também troca significante desde uma idade muito precoce. Segundo Dolto (1984), o desejo de comunicação sutil (não alimentar) precede a necessidade de comunicação substancial (pelo alimento). Mas é pelo grito e pelos sons que sobrevêm com as modificações corporais que podemos ver de maneira clara como o bebê entra na linguagem. Essas modificações corporais trazidas pela necessidade são tomadas pelo Outro como mensagens. Pela palavra do Outro o bebê recebe suas mensagens de volta, o que implica ser reconhecido como sujeito de desejo. Por seus gritos, seus choros, seus sons reconhecidos como demanda de amor pelo Outro, a criança procura preencher sua falta a ser, primeiro na relação com o seio e, quando este vem a faltar, por intermediário da palavra.

A entrada da criança na linguagem pode ser mais bem compreendida se fizermos uma articulação entre a psicanálise, que procura supor desejos subjacentes aos comportamentos, e a psicolingǘstica, que descreve comportamentos de linguagem a partir da observação. Os dois campos são complementares, e essa articulação vem nos mostrar como o comportamento do bebê não é mais que o reflexo de sua atividade mental e de sua entrada gradativa na linguagem.

A partir das pesquisas psicolingüísticas, sabemos que o feto ouve desde os 3 meses, que ele ouve as vozes do pai e da mãe, fazendo desde cedo a distinção entre voz feminina e voz masculina, entre som grave e som agudo, e que ele é capaz de discriminar certas seqüências sonoras. Além disso, ele parece ter uma memória que conserva o traço de certos estímulos além do nascimento, como mostraram algumas experiências feitas com canções desde os 5 meses de gravidez. Parece ainda que ele reconhece quando nos dirigimos a ele, o que Marie-Claire Busnel (1998) explica pelo fato de que a mãe fica mais emocionada, e sua prosódia é diferente de quando se dirige a outra pessoa. Todas essas capacidades se complexificam com o nascimento. Muito cedo o lactente mostra uma preferência pela voz materna e mesmo pela língua materna. A voz da mãe, por sua repetição, vem marcar o ouvido do bebê com palavras, frases, canções, cujo sentido o bebê não compreende da 
mesma maneira que o adulto. Sua compreensão é primeiramente, se seguimos Dolto, a da imagem do corpo oral. Graças à repetição, progressivamente, a sensação auditiva referida à cadeia de significantes, que é antes de tudo percepção de um som, torna-se em seguida a percepção de um discurso, ou seja, a voz prende-se na alucinação e depois na representação, ao mesmo tempo em que o discurso da criança estrutura-se progressivamente desde o grito às lalações, ao balbucio, às palavras e às frases. No seminário sobre $A$ relação de objeto (1956-7), Lacan afirma que a criança entende muito mais a estrutura da palavra do adulto, antes de perceber o sentido, e que isso seria uma primeira forma de supereu. Essa percepção da estrutura antes da percepção do sentido é bem confirmada pela observação dos psicolingüistas, como veremos em seguida.

A mensagem sonora da mãe é, num primeiro tempo, um enigma para o bebê. Ele pergunta-se o que é que ela quer dele, ele procura identificar-se a uma demanda que não sabe bem o que é, isso é o "che vnoi", o bebê procura identificar o que falta à sua mãe. O enigma é a primeira forma de demanda. Se inicialmente a reação da criança é simultânea à voz da mãe, aos poucos, não será mais simultânea. Ela vai procurar ocupar os intervalos do discurso dela, vai tentar preencher seu vazio. Essa questão, o que é que a mãe deseja, ele vai se pôr, entretanto, durante muito tempo. É o que vai se manifestar nos porquês intermináveis da criança. O che vuoi transforma-se mais tarde em "que lugar e que importância tenho para meus pais". Procurando identificar o que falta à mãe, a criança supõe que o que ela deseja é o falo e procura, então, identificar-se a seu falo.

É em torno dos 2 meses, que o bebê começa a sair de sua passividade, de sua reação corporal simultânea à voz da mãe e começa a fazer sons mais aperfeiçoados que o grito, do tipo vocalizações e jogos vocais, tais como as lalações e o gorjear, procurando alucinar a voz da mãe quando esta se afasta. Esses sons são, primeiramente, pura música, pura melodia, puro jogo de gozo, que a criança pode produzir também em resposta à demanda da mãe. Quando está sozinha em seu berço, ela presentifica a mãe com esses sons, acreditando repetir fonemas que ouviu dela. Dolto (1984) afirma que é tão precoce esse desejo de ouvir de novo a vOz da mãe, que muito rapidamente a criança torna-se incapaz de pronunciar os fonemas que não pertencem a sua língua materna efeito da dominância do princípio do prazer -, quando podia no início pronunciar os fonemas de todas as línguas. Lacan nos fala do puro jogo da palavra no lugar do Outro no seminário sobre $A$ angústia (1962-3), quando evoca o monólogo hipnopômpico do lactente, dizendo que, embora toda função de comunicação esteja 
excluída, as conseqüências desse jogo são a constituição da voz e do sujeito. Lacan põe a voz em relação com o vazio do Outro e o desejo do Outro, relação que se faz no modelo da anátomo-fisiologia do aparelho auditivo, ou seja, o órgão da audição é um vazio cuja estrutura determina os sons que nele ressoam vindos do exterior. A voz ressoa não no vazio do caracol, mas no vazio do Outro, e ela só pode ressoar se toma corpo na relação entre a mãe e a criança.

Vemos assim que a voz, a palavra, a língua são também instrumentos de gozo, e que isso é particularmente visível durante o primeiro ano. O ser humano desde sempre se entretém com a língua e com a voz, assim como com o seio, uma relação de natureza erótica, a voz e a língua podem ser objetos ora de amor, ora de ódio, ora objetos de gozo. Assim acontece na fase do gorjear, das lalações e depois do balbucio, é o registro do Eu prazer. Somente depois a palavra adquire valor utilitário para comunicar mensagens. Num primeiro momento, a linguagem é puro gozo, pura música, essa que o bebê escuta de sua mãe, assim como seu jogo com as sonoridades, que se tornará em seguida jogo com o sentido, sempre em obediência ao princípio de prazer. Podemos observar a sobrevivência desse jogo com os sons no adulto, nas vocalizações, no canto sem palavras, ou na dessemantização da palavra, como acontece particularmente na ópera e na música lírica em geral, em que o som é puro prazer, jogo de vertigem, jogo de gozo, dominância absoluta do princípio de prazer. Talvez possamos dizer a mes- 
ma coisa da fuga de idéias do maníaco. A música pura é anterior ao sentido, ela está fora da história, reenvia às origens e, portanto, aos mitos das origens. Não é por nada que Freud põe em relação música e mitos endopsíquicos na Carta 78 a Fliess (1897).

Essa estrutura que, segundo Lacan, a criança percebe na sonoridade da voz da mãe, Alain-Didier Weill (1998) nos diz que não pode ser outra senão a estrutura musical, a estrutura harmônica com uma chave, uma tonalidade dominante, uma tônica e um ritmo, mas articulada também à estrutura fonemática de uma língua particular, a língua materna. Por essa estrutura, a emissão dos sons segue certas leis, as leis da harmonia, as leis da língua, o que faz com que eles não possam ser ditos de qualquer jeito, nem em qualquer ordem. Ao mesmo tempo, na maneira como se combinam - por exemplo, que tipo de acorde se constrói na combinação da voz da mãe com a voz do pai, consonante, dissonante, ou não há acorde possível? - e se seguem com sua melodia, seu ritmo e suas modulações, se é também por assonâncias, consonâncias ou dissonâncias, nós vimos que a mãe transmite seus conflitos e seus dilemas, assim como a solução que dá a esses dilemas.

As crianças percebem essa estrutura porque são capazes de registrar as freqüências desde a vida intra-uterina. Essa aptidão precoce nos bebês, que faz com que possam discriminar os sons das línguas faladas, é chamada pelos psicolingüistas de percepção categorial. Eles são sensíveis às variações de duração, de altura e de intensidade que organizam a cadeia falada em unidades prosódicas e em unidades funcionais recorrentes, como frases e sintagmas, o que faz com que memorizem a organização melódica da palavra ainda na vida fetal. É assim que um bebê de 4 meses e meio consegue detectar as fronteiras de frases em todas as línguas, porque é sensível às diferentes tonalidades, às modulações, à repetição das cadências e dos ritmos. Ele perde rapidamente essa capacidade e só retém em seguida os índices que são pertinentes à sua língua. Entre 4 e 6 meses ele elimina do tratamento os índices que não são pertinentes a um grupamento funcional de sua língua, como a frase, por exemplo, e só retém os índices que são úteis para os grupamentos funcionais de sua língua. É por essa aptidão, em que a palavra não é tomada como uma onda contínua, que o bebê reconhece progressivamente as pausas, as paradas e os grupamentos que marcam o fim das frases, o fim dos sintagmas e a diferença entre as palavras, em todas as línguas.

O caminho para o sentido é que, quando a criança produz um som, a mãe, assim como faz com o grito, investe-o de sentido, investe-o falicamente, ela ouve mais que o som, ela interpreta-o e responde a ele. Sua capacidade de ilusão anteci- 
patória a faz supor seu filho sujeito bem antes que ele fale, bem antes da divisão subjetiva. Isso faz com que fale no lugar da criança, dando sentido a seus comportamentos, enunciando o desejo dela em seu lugar, caracterizando o que Winnicott chamou de preocupação materna primária (1956). É assim que a voz prende-se na alucinação e em seguida na representação. Pelas lalações, os bebês tentam reenviar à mãe a organização melódica que percebem nela. Logo reproduzem os diálogos sozinhos e pouco a pouco se tornam interlocutores, dialogando com ela, quando se situam então como ativos no diálogo. É isso que os psicolingüistas chamaram de "protoconversações", turn talking, que se observam entre 2 e 3 meses. As protoconversações são atividades rítmicas partilhadas, descritas como a troca de expressões entre a mãe e a criança, do rosto, da voz, do olhar e dos movimentos, trocas que ocorrem num certo ritmo. A criança dá a impressão de compreender muito bem o que a mãe diz e age como se assim fosse. Ela faz muito esforço para se exprimir, com movimentos da língua e da boca procurando pronunciar as sílabas com movimentos sincronizados à palavra do outro. É como se todo o corpo do bebê entrasse na linguagem, no ritmo da palavra do adulto, tudo se torna sincronizado entre ele e o Outro, e todos os seus movimentos exprimem sua atividade emocional interior que está em relação com a emoção do Outro. A criança responde à frase da mãe com sons que se assemelham à melodia de sua frase, de maneira rítmica, adaptando-se ao ritmo e à freqüência da mãe ou do pai, revelando assim uma espécie de divisão primitiva entre demanda e resposta à demanda, divisão esta anterior à Spaltung. Ao mesmo tempo, ela revela assim uma certa capacidade de espera da satisfação. Essa entrada no ritmo do adulto vê-se não somente no nível da linguagem. Poder-se-ia talvez dizer que a entrada no ritmo da linguagem é o reflexo do ritmo de amamentação e de presença-ausência. $\mathrm{O}$ ritmo da criança harmoniza-se com o ritmo do adulto e com o ritmo do meio que a cerca, essa organização invadindo de certa maneira toda a vida do bebê. O fato é que em torno dos 3 meses, as mães referem freqüentemente que só então começam a poder dormir um pouco mais à noite e a terem pequenos momentos para elas.

Esse comportamento também é nítido quando se vê o bebê participar das canções cantadas pela mãe. Os movimentos de seu corpo são tomados pela canção e entram em sincronia com as estruturas rítmicas da palavra cantada pelo adulto. Os gestos da criança revelam os movimentos da voz da mãe. A mesma coisa 
passa-se nas protoconversações, tudo é tomado na linguagem, todas as formas de expressão, quer sejam os sons ou os movimentos do corpo. O que se pode observar nas protoconversações é que a reação à voz não é mais simultânea. Aqui a criança espera o silêncio da mãe para responder e faz silêncio em seguida para deixar a mãe se manifestar, o que nos mostra de maneira clara como ela é aspirada pelo Outro, como ela é tomada na linguagem desde seus primeiros dias, como seu corpo é tomado na demanda do Outro e como ela começa a fazer sons no silêncio do Outro em sua tendência a preencher seu vazio.

O balbucio que é um início de pronunciação de sílabas tendo formas de sílabas da língua adulta, instala-se no final do turn talking. Vimos que em torno de 4 a 6 meses a criança perde a capacidade de perceber os grupamentos funcionais que não pertencem à sua língua, excluindo do simbólico o que vem se constituir no Real. Entre 6 e 8 meses surge uma linguagem modulada que não segue ainda as regras gramaticais, as palavras não são ainda reconhecíveis, mas a criança torna-se capaz de manipular pessoas à distância, pois a mãe reconhece em seus sons a intenção do desejo. Por seus sons, ela pode fazer voltar o outro quando tem vontade. Isso acontece ao mesmo tempo em que a criança começa a brincar de deixar cair os objetos, o que nos leva a concluir que ela utiliza a linguagem nesse momento como o fort-da, como um jogo com o qual manipula as pessoas como brinquedos, afastando-as e fazendo-as voltar. Aos 7-8 meses elas conseguem distinguir uma palavra, mas sem compreendê-las, discriminando as formas verbais recorrentes na palavra que ouve. É nesse momento que começa a reconhecer de maneira prevalente seu nome.

O balbucio é ainda gozo, mas já gozo vocálico consonântico formando as primeiras sílabas oposicionais, sem ser ainda designação de alguma coisa. A designação das coisas sobrevém depois, com o julgamento de existência e a fase do espelho, momento em que as palavras são postas em relação com as coisas, com os objetos. No balbucio há introdução da consoante, que corta a continuidade das vogais, articulando-as e fazendo sobrevir a silabização dupla, papai, mamãe, cocô, e finalmente a nomeação dos outros objetos. Dolto (1984) nos diz que é o duplo ritmo, o fato de que a criança duplica-se quando a mãe está presente, e desduplica-se quando ela se vai, que explica essa silabização dupla das primeiras palavras que a criança pronuncia. As primeiras palavras são repetitivas de duas sílabas, correspondentes ao sentimento de existir da criança, conjuntamente com sua mãe, desdobramento de suas sensações. Isso corresponde também ao ritmo de dois tempos que predomina nessa época, o ritmo da presença/ausência e do sentimen- 
to diferente de suas sensações quando a criança está com ou sem a mãe. Dolto (1984) nos diz ainda que essas palavras vocalizadas são talvez objetos transicionais sonoros, que a criança guarda na memória, antes que se tornem verdadeiras palavras. Lacan lembra-nos no seminário sobre $A$ angústia (1962-3) que essas primeiras palavras, papai e mamãe, são articuladas no nível labial, que os lábios são a imagem do corte que induz o fantasma do seio como seccionado, o que lembra o corte instituído pela articulação significante. José Roberto de Almeida Correia, em artigo intitulado "O tema do duplo pode esclarecer sobre o autismo e a linguagem?," observou que os autistas, quando começam a falar, não fazem essa silabização dupla como as outras crianças, o que nos faz pensar que isso é também metáfora da alienação no Outro, que não ocorre no autista. O autista é desmamado de saída, nos diz Marie-Christine Laznik, em seu livro Rumo à palavra, sem jamais se alienar no Outro. Enfim, essa silabização dupla, e essa duplicação das sensações, podemos dizer que é também atividade negativante. Atividade negativante, que, paradoxalmente, podemos dizer positiva, na medida em que ao mesmo tempo em que corta, ela age no sentido de estabelecer ligações, portanto, no sentido das pulsões de vida. Mas a introdução da consoante indica, além do mais, que alguma coisa começa a escapar do gozo vocálico. O corte introduzido pela consoante é em si mesmo um passo para a separação, para o gozo fálico, é nessa época que a criança começa a gostar de partilhar um objeto 
com os outros, um objeto torna-se significante dela diante dos outros, do qual ela começa a perceber o mesmo sentido que as outras pessoas. Ela entra no pacto que constitui a nomeação, que faz com que dois sujeitos, ao mesmo tempo, concordem em reconhecer o mesmo objeto. É a abertura para a significação fálica. Lacan nos diz no Seminário II (1954-5) que, se os sujeitos não se entendem sobre esse reconhecimento, não há mundo que possa se manter um instante.

Em torno de 9 meses, portanto, o bebê começa a se dar conta de que as palavras têm um sentido. Aos 10 12 meses, ele só discriminará os sons que fazem sentido em sua própria língua e começará a dizer suas primeiras palavras. A escuta focaliza-se daí por diante não somente nas unidades funcionais prosódicas e melódicas da língua, mas, sobretudo, na procura de um sentido. O comportamento de apontar com o dedo que sobrevém nesse momento é bem indicativo da procura do sentido. A criança parece pedir ora o próprio objeto, ora perguntar o sentido desse objeto, ela quer saber o que é cada objeto que vê. Se a mãe compreende esse gesto apenas como pedido do objeto, não compreendendo sua procura de sentido, a criança corre o risco de ter um atraso da linguagem. Essa apreensão do sentido é o que os psicolingüistas chamam a compreensão simbólica, que se manifesta no fato de que as crianças respondam ao adulto de maneira adequada. E, aí, a criança entra numa temporalidade diferente, pois é preciso esperar a última palavra da frase para poder responder. É o efeito nachträgli- ch. A criança entra na história, entra na narrativa, na diacronia propriamente dita. Isso quer dizer também que começa a se submeter ao princípio da realidade. Estamos agora no registro do Eu realidade, que, ao inverso do Eu prazer, obedece às regras de ligações. Entre 18 e 20 meses, há um crescimento do vocabulário, a criança começa a levar em conta as regras de pronúncia e os princípios gramaticais da língua, e começa a aplicar essas regras. Isso acontece sempre nessa dialética entre pulsão de vida e pulsão de morte. Efeito da $B e$ jahung e do Eros, efeito das pulsões de vida, que funcionam no sentido da unificação e da articulação entre os elementos separados, para estabelecer uma relação entre eles. Efeito também da fase do espelho, com sua tendência a ligar e a unir. Mas também efeito das pulsões de destruição que introduzem o corte. Assim, afirma Jean-Jacques Rassial (em seminário de DEA na Universidade de Paris XIII, em 1998), o balbucio tornase língua sob o efeito das leis de concatenação e de reunião, ao mesmo tempo em que há exclusão, Austossung, de algumas produções fonemáticas que não pertencem à língua materna, efeito da pulsão de destruição. Esse autor considera que as produções ecolálicas devem ser compreendidas como produção fonemática foracluída, expulsa no Real. Esse tipo de foraclusão efetua-se não somente no psicótico, mas também no neurótico, que pode também expulsar sinais de percepção que não irão se constituir em significantes. Em conseqüência disso, o adulto terá dificuldades em aprender uma língua estran- 
geira, pois, na língua estrangeira, deve reencontrar produções fonemáticas que estiveram à sua disposição na época do balbucio e das lalações, mas que foram expulsas como não pertencentes à língua materna. Essa foraclusão acontece porque a criança identifica no nível da onda sonora produzida uma certa freqüência que não é aquela que deseja ouvir, não é aquela que faz voltar sua mãe.

Quando a dimensão do sentido sobrevém é que houve a divisão originária que faz advir o sujeito, a Spaltung entre discurso consciente e discurso inconsciente. Essa divisão manifesta-se no discurso em sujeito do enunciado e sujeito da enunciação. A criança sai do gozo incestuoso, do gozo proibido do seio e das lalações, para entrar no gozo permitido, gozo fálico. Segundo Lacan (1948), somente um sujeito pode compreender um sentido, de maneira que todo fenômeno de sentido implicaria um sujeito. Dolto (1984) afirma, por seu lado, que a compreensão de uma palavra é diferente segundo a fase em que está. Por exemplo, se a criança está no momento da imagem de base oral, ela só compreende as palavras que concernem aos prazeres da boca e de corpo carregado. A compreensão de uma palavra depende para ela ao mesmo tempo do esquema corporal de cada um e da constituição da imagem do corpo ligada às trocas vivas que acompanharam a aquisição dessa palavra. E, embora Dolto (1984) nos diga que a palavra tem um sentido simbólico em si mesmo, pois reúne além do espaço e do tempo seres humanos na comunicação, ela afirma que aquele que não tem esquema corporal ou imagem do corpo correspondente à palavra emitida ouve a palavra sem compreender o sentido, por não ter uma relação corporal que permita. Lembramos que, para adquirir sentido, as palavras devem tomar corpo e serem metabolizadas numa imagem do corpo relacional. Sem isso, a criança terá dificuldade em compreender o sentido. As palavras tomam corpo na fase do espelho, quando são associadas às coisas. Não nos podemos impedir de lembrar aqui uma criança psicótica de 2 anos e meio que pronunciava somente duas ou três palavras, e a palavra que pronunciava mais freqüentemente era uma que tinha ouvido de um vendedor que passava diariamente diante de sua casa, de quem jamais tinha visto o rosto. Era, portanto, uma voz que vinha do além, sem nenhuma relação a um corpo, essa criança não podendo, evidentemente, compreender o sentido.

Dolto (1984) nos diz que a castração oral é decisiva para a compreensão das palavras, pois ela considera que é somente a partir dessa castração que a significação das palavras terá um outro alcance. Ela confirma assim mais uma vez como o corpo está em questão no sentido das palavras e como a zona erógena proibida é o lugar em que o sentido deve advir. É finalmente pela castração 
oral que a criança entra definitivamente na significação fálica. Ela se introduz na relação com outras pessoas, daí por diante poderá aceitar a assistência de outras pessoas que não a mãe, se naturalmente essas pessoas estiverem em boas relações com ela.

A angústia do oitavo mês descrita por Spitz é compreendida também como atividade negativante da linguagem contemporânea do desmame, antes da pronunciação do não na palavra. A criança diz não a um rosto diferente dos rostos que conhece. É um não motor, ainda não verbal, pois ela dá as costas para o estrangeiro e chora, mas se volta para a pessoa que conhece. Negação e afirmação, atividade de simbolização ao mesmo tempo. O que angustia a criança, nos diz Claude Trevarten (1998), não é o medo de ser comido ou de ser morto pelo estranho, o que a criança sente como perigoso é justamente o fato de não compreender o sentido da presença estrangeira. Para Françoise Dolto, a angústia do oitavo mês não é uma passagem fatal nem necessária, ela sobrevém nas crianças que não foram suficientemente carregadas em direção do que as atrai, e a quem o adulto não mediatiza suficientemente no espaço os objetos que vê e que deseja tocar. Isso daria à criança um sentimento de impotência, pois ela não liga o estrangeiro às lembranças anteriores. Se não pode ligar o estranho às lembranças anteriores, não poderá evidentemente compreender o sentido. De fato, tudo é outro, tudo é estrangeiro para o recém-nascido, nada tem sentido até que a mãe dê sentido com sua interpretação e com 
suas palavras, fazendo a ligação do novo com as experiências passadas. É por isso que, quando a criança começa a falar, fala do lugar da mãe que antes falava em seu lugar, sua frase fala de seu desejo, mas como se fosse dito por um outro, pela mãe, o verbo na terceira pessoa. É somente mais tarde, que se dá a inversão pronominal, e que a criança fala de si na primeira pessoa do verbo.

Depois do desmame, portanto, a boca esvaziada do seio dá lugar a uma outra forma de comunicação. O prazer da boca desloca-se progressivamente para a pronúncia das palavras e para o conhecimento de outros objetos que se constituem primeiramente como objetos mamãizados (objetos que são associados pela criança à presença da mãe), as próprias palavras se constituem como objetos mamãizados. Dolto (1984) nos diz que a castração oral é simbolígena, na medida em que a assimilação da língua materna só se faz depois do desmame.

Essa linguagem de gozo, nos diz Lacan (1975) na "Conferência de Genebra sobre o sintoma", intervém sob a forma de alingua, primeira marca do ser falante. Se a língua é condição do inconsciente, a alíngua é a língua particular e única para cada ser falante. A alíngua sobrevém para o ser por meio de cortes, escansões, pontuações, que instauram para sempre o equívoco. A alíngua é a língua do inconsciente de cada um, ela estrutura o falasser, e constitui o substrato em que o sujeito estrutura suas experiências. $\mathrm{O}$ falasser constitui-se como marcado pelo significante e pela castração e, portanto, incapaz de dizer tudo.

Tomando a cadeia significante, podemos dizer que S1 ainda não é comunicação nem sentido. São as lalações, é o balbucio, é alingua, puro gozo que se articula com o objeto voz. Esse gozo se tornará sentido, jouis-sens, articulado com um outro significante, o $\mathrm{S} 2$, que desloca o gozo do puro som para o sentido, momento em que o simbólico advém pela metáfora paterna. Isso se dá por meio da negação, que transforma S1 em S2 para que haja acesso à cadeia significante consciente, pois para o inconsciente não há negação. A Verneinung implica desdobramento, implica negação. Se há foraclusão do nome do pai, as pulsões ficam separadas, desarticuladas, a negação não pode se inscrever na linguagem, haverá portanto carência de nexo, de ligações, o que se manifesta na proliferação imaginária do psicótico. Sua linguagem será difícil de ser entendida pelos outros. Para que a negação inscreva-se na linguagem, é preciso que as palavras ditas pela mãe venham inibir a alucinação primitiva, tornando possível a atividade negativante.

Podemos ainda fazer observar que a articulação entre esses dois momentos, o primeiro momento, em que a linguagem não 
tem sentido, as palavras não têm nexo, nem ligação, e o segundo momento, em que o sentido advém, as palavras ligam e articulam-se entre si, esse momento de virada é dado pelo espelho, que, segundo Lacan, é o que estrutura tudo o que existe no homem de sem ligação, de fragmentado, de anárquico, e que estabelece a relação das palavras com as percepções.

A nomeação dos objetos estrutura a percepção e organiza as sensações. No texto "Agressividade em psicanálise”, Lacan (1948) afirma que o narcisismo que advém pelo espelho revela o mais profundo sentimento das latências da semântica. Essa virada dá-se então a partir do reconhecimento do sujeito no espelho, e em toda percepção o homem se reconhecerá sempre em um ponto qualquer ou em vários pontos. Pela nomeação dos objetos, o homem os faz subsistir no tempo. Eles duram além de seu desaparecimento no espaço. O nome é o tempo do objeto, afirma ainda Lacan (1954-5) no Seminário II.

\section{REFERÊNCIAS BIBLIOGRÁFICAS}

Bergès, J. \& Balbo, G. (1998). Jeu des places de la mère et de l'enfant: Essai sur le transitivisme. Paris: Erès.

Boysson-Bardies, B. (1998). Naissance de la parole chez le nourrisson. Journées Émergence du Langage Chez. le Nourrisson. Paris: inédito.

Busnel, M.-C. (1998). L'audition prénatale et son rôle dans la relation mère et nouveau-né. Journées Émergence du Langage Chez le Nourrisson. Paris: inédito.
Busnel, M.-C. \& Granier-Deferre, C. (1982). L'audition prénatale. Cabiers du NouveauNé, no 5, L'Aube des Sens, pp. 147-75.

Cabassu, G. (1998). Les nourritures terrestre: Paroles ou aliments? Journées Émergence du Langage Chez. le Nourrisson. Paris: inédito.

Cesarotto, O. (1985). Psilacánise: Algumas reflexões sobre o espelbo, por Jacques Lacan. São Paulo, SP: Clínica Freudiana.

Dehaene, G. \& N. (orgs.) (1998). Le développement du langage: Tout est-il joué dans la première année de vie? Journées du 5 Avril. La Fédération des GEN, Le GEN UP RP à l'Amphithéâtre de l'Hôpital Bicêtre. Laboratoire Guigoz.

Dolto, F. (1984). L'image inconsciente du corps. Paris: Seuil.

Fink, B. (1998). O sujeito lacaniano - Entre a linguagem e o gozo. Rio de Janeiro, RJ: Jorge Zahar.

Fonsêca, L. (org.) (1999). A angústia: Reflexões. Tomo I. Recife, PE: CEF. (2000). L'angoisse: Réflexions. Edição bilíngüe. Tomo II. Recife, PE: CEF, $271 \mathrm{p}$.

Freud, S. (1895). Esquisse d'une psychologie scientifique. In La naissance de la psychanalyse. Paris: PUF, 1991, $6^{a}$ ed., pp. 307-96.

(1897). Lettre 78. In La naissance de la psychanalyse. Paris: PUF, 1979, pp. 210-1.

(1905). Três ensaios sobre a teoria da sexualidade. In Edição standard brasileira das obrasa completas de Sigmund Freud (J. Salomão, trad.). Rio de Janeiro, RJ: Imago, 1989, Vol. VII, pp. 117-228.

(1910). Un souvenir d'enfance de Léonard de Vinci. Edição bilíngüe. Paris: Gallimard, 1991, 277 p.

(1913). Totem et tabou. Paris: Payot, 1965, 242 p.

(1915). Pulsions et destins des pulsions. Col. Folio/Essais. In Métapsycho- 
logie. Paris: Gallimard, 1968, pp. 11-43. (1920). Au-delà du principe de plaisir. In Essais de psychanalyse. Paris: Payot, 1981, pp. 41-115.

(1925-6). Inibições, sintomas e ansiedade. In Edição standard brasileira das obrasa completas de Sigmund Freud (J. Salomão, trad.). Rio de Janeiro, RJ: Imago, 1976, Vol. XX, pp. 93-199.

(1929). Le malaise dans la culture. Paris: Quadrige/PUF, 1997, 2a ed., $93 \mathrm{p}$.

Garcia-Rosa, L. A. (1991). Introdução à metapsicologia freudiana. Vol. 1. Rio de Janeiro, RJ: Jorge Zahar, 209 p.

Geets, C. (1971). Mélanie Klein. Col. Psychothèque. Paris: Éditions Universitaires, $160 \mathrm{p}$.

Herbinet, E. \& Busnel, M.-C. (dirs.) (1982). Les Cabiers du Nouveau-Né, no 5 . L'Aube des Sens, $414 \mathrm{p}$.

Hyppolite, J. (1966). Commentaire parlé sur la Verneinung de Freud. In Lacan, J. Écrits. Paris: Seuil, pp. 879-87.

Klein, M. (1932). Le sevrage. Le Discours Psychanalytique, ano 2, $\mathrm{n}^{\circ}$ 5, dez. de 1982; ano $3, n^{\circ} 1$, mar. de $1983 ; n^{\circ} 2$, jun. de 1983.

(1952). Algumas conclusões teóricas relativas à vida emocional do bebê. In Inveja e gratidão e outros trabalhos. Obras Completas. Vol. III. Rio de Janeiro, RJ: Imago, 1991.

Kristeva, J. (1981). Le langage cet inconnu: Une initiation à la linguistique. Paris: Seuil, 336 p.

Lacan, J. (1948). L'agressivité en psychanalyse. In Écrits. Paris: Seuil, 1966, pp. $101-$ 24.

(1949). Le stade du miroir comme formateur de la fonction du je. In Écrits. Paris: Seuil, 1966, pp. 93-100.

(1954-5). O seminário, Livro II,

O eu na teoria de Freud e na técnica da psicanálise. Rio de Janeiro, RJ: Jorge Zahar, 1978, 415 p.
(1956). Fonction et champ de la parole et du langage en psychanalyse. In Écrits. Paris: Seuil, 1966, pp. 237-322. (1956). Introduction au commentaire de Jean Hyppolite sur la Verneinung de Freud. In Écrits. Paris: Seuil, 1966, pp. $369-80$.

(1956). Réponse au commentaire de Jean Hyppolite sur la Verneinung de Freud. In Écrits. Paris: Seuil, 1966, pp. 381-99.

(1956-7). Le Séminaire, Livre IV, La relation d'objet. Paris: Seuil, 1944, 446 p. (1958). La signification du phallus. In Écrits. Paris: Seuil, 1966, pp. 685-95.

(1960-4). Position de l'inconscient. In Écrits. Paris: Seuil, 1966, pp. 829-50.

(1962-3). L'angoisse. Publicação não-comercial. Documento interno da Association Freudienne.

(1975). Conferencia en Ginebra sobre el síntoma. In Intervenciones y textos 2. Buenos Aires: Manantial, 1988.

Laznik-Penot M.-C. (1990). La mise en place du concept de jouissance chez Lacan. Revue Française de Psychanalyse, $n^{\circ} 1,55-81$.

Laznik-Penot, M.-C. (org.) (1994). O que a clinica do autismo pode ensinar aos psicanalistas. Salvador, BA: Ágalma, 152 p.

Laznik, M.-C. (1995). Vers la parole: Trois enfants autistes en psychanalyse. L'espace analytique. Paris: Denoël, 316 p.

(1998). A voz como primeiro objeto da pulsão oral. Estilos da Clínica: Revista sobre a Infância com Problemas, 5 (8), 2000, 76-90.

Oliveira, W. de (1924). A musicotherapia. Tese. Salvador, BA: Imprensa Oficial do Estado, $137 \mathrm{p}$.

Pommier, G. (1998). La question de l'origine du langage, à l'écoute des adultes. Journées Émergence du Langage Chez le Nourrisson. Paris: inédito.

Priolli, M. L. M. (1965). Princípios básicos da 


\section{Dossiê}

música para a juventude. $1^{\circ}$ Vol. Rio de Janeiro, RJ: Arthur, 142 p.

Reik, T. (1984). Écrits sur la musique (Cl. Davenet, trad. do inglês). Paris: Les Belles Lettres, $270 \mathrm{p}$.

Rondal, J.-A. (1983). L'interaction adulte-enfant et la construction du langage. Bruxelas: Pierre Mardaga, 197 p.

Rosolato, G. (1980). Musique: Mémoire, oubli. Diapason, 67-8.

Tomatis, A. (1980). La musique: Notion indispensable et pourtant supposée superflue. Diapason, nov., 93-7.

Trevarten, C. (1998). Recherches actuelles sur l'investissement du rythme et du langage par le nourrisson. Journées Émergence du Langage Chez le Nourrisson. Paris: inédito.

Yaguello, M. (1981). Alice au pays du langage. Paris: Seuil, 218 p.

Vasse, D. (1977). O umbigo e a voz. Col. do Centro de Estudos Freudianos (L. J. Gaio, trad.). São Paulo, SP: Loyola.

Wallon, H. (1983). Les origines du caractère chez. l'enfant. Paris: Quadrige/PUF, 8 a ed., $302 \mathrm{p}$.

Weill A.-D. (1998). D'une pulsion invocante. Journées Émergence du Langage Chez, le Nourrisson. Paris: inédito.

(1999). Invocações: Dionísio, Moisés, São Paulo e Freud (D. D. Estrada, trad.). Rio de Janeiro, RJ: Companhia de Freud,160 p.

Winnicott, D. W. (1956). La préoccupation maternelle primaire. In De la pédiatrie à la psychanalyse. Paris: Payot, 1969, 372 p. (1969). De la pédiatrie à la psychanalyse. Paris: Payot, $372 \mathrm{p}$.

(1980). L'enfant et le monde extérieur. Paris: Payot, 179 p.

(1981). L'enfant et sa famille. Paris: Payot, 214 p.

Recebido em setembro/2002.

Aceito em janeiro/2003. 